\title{
Synthesis of $\alpha$-galactosyl ceramide and the related glycolipids for evaluation of their activities on mouse splenocytes
}

\author{
Gang-Ting Fan,, ${ }^{\text {ab }}$ Yi-shin Pan, ${ }^{a}$ Kuo-Cheng Lu, ${ }^{a}$ Yu-Pei Cheng, ${ }^{a}$ Wan-Chen Lin, ${ }^{b}$ Steven Lin, \\ Chun-Hung Lin, ${ }^{\mathrm{a}, \mathrm{c}}$ Chi-Huey Wong, ${ }^{\text {a,c }}$ Jim-Min Fang ${ }^{\mathrm{a}, \mathrm{b}, *}$ and Chun-Cheng Lin ${ }^{\mathrm{a}, \mathrm{d}, *}$ \\ ${ }^{a}$ Institute of Chemistry and Genomic Research Center, Academia Sinica, Nankang, Taipei 115, Taiwan, ROC \\ ${ }^{\mathrm{b}}$ Department of Chemistry, National Taiwan University, Taipei 106, Taiwan, ROC \\ ${ }^{\mathrm{c}}$ Institute of Biological Chemistry, Academia Sinica, Nankang, Taipei 115, Taiwan, ROC \\ ${ }^{\mathrm{d}}$ Department of Applied Chemistry, National Chiao Tung University, Hsinchu 300, Taiwan, ROC
}

Received 13 October 2004; revised 1 December 2004; accepted 3 December 2004

Available online 11 January 2005

\begin{abstract}
Phytosphingosine and its short-chain analog were efficiently synthesized with $19 \%$ overall yield in 10 steps, respectively, starting from an inexpensive D-lyxose. Galactosyl donors of sulfide and phosphite types bearing benzoyl protecting groups of 4- and 6-OH underwent glycosylation in excellent $\alpha$-anomeric selectivity. A variety of $\alpha$-galactosyl, fucosyl and glucosyl ceramides and serine-type lipids were prepared, and their activities involved in the proliferation of mouse splenocytes and the expression of cytokines were elucidated. Besides $\alpha$-galactosyl ceramides, a galactosyl serine-type lipid also exhibited substantial effect on the expression of cytokines IFN- $\gamma$ and IL-4.

(C) 2004 Elsevier Ltd. All rights reserved.
\end{abstract}

\section{Introduction}

CD1 molecules are $\beta 2$-microglobulin-associated proteins that are related to MHC I and II molecules. ${ }^{1}$ Four CD1 isoforms, CD1a, CD1b, CD1c, and CD1d, have been found in humans. ${ }^{2}$ Only human CD1d is homologous to mouse and rat CD1 molecules. ${ }^{3}$ This protein is normally expressed by thymocytes and various cells with antigen-presenting functions, such as B cells and dendritic cells. The primary function of CD1 proteins is to present glycolipid antigens through lipid-protein interactions with receptors on T-cells, and thus activating the immune system. ${ }^{4}$ The analysis of amino acid sequences reveals that CD1 molecules have highly hydrophobic antigen-binding grooves, ${ }^{1}$ The X-ray diffraction analysis further indicates that the crystal structure of mouse CD1d has a hydrophobic antigenpresenting groove with two large pockets, which can probably accommodate the lipid tails of antigens. ${ }^{5}$

In 1993, six species of bioactive glycolipids having $\alpha$-galactosylceramide structures were isolated from the marine sponge Agelas mauritianus. ${ }^{6}$ Years later, KRN7000 (also called $\alpha$-GalCer for common use) was chosen from the

Keywords: Phytosphingosine; $\alpha$-Galactosyl ceramide; Immuno stimulator; Glycolipid.

* Corresponding authors at present address: Institute of Chemistry and Genomic Research Center, Academia Sinica, Nankang, Taipei 115,

Taiwan, ROC; e-mail: cclin@chem.sinica.edu.tw derivatives of these structures as a candidate for clinical applications. ${ }^{7}$ The $\alpha$-GalCer can be recognized by an entire population of mouse and human CD1d-restricted lymphocytes. ${ }^{8}$ An unusual feature of $\alpha$-GalCer is the $\alpha$ anomeric linkage of galactose to the lipid, unlike the ubiquitous $\beta$-glycosidic bond in nearly all known natural glycosphingolipids of normal mammalian cells. $\alpha$-GalCer stimulates the fast release of large amounts of cytokines from most mouse NKT cells, ${ }^{8}$ which are characterized by expression of an invariant V $\alpha 14$ TCR. ${ }^{9}$ Interaction of $\alpha$-GalCer with CD1 receptors causes $\mathrm{T}$ cells to secrete primarily interferon $\gamma$ (IFN- $\gamma$ ) and interleukin-4 (IL-4) resulting in $\mathrm{TH} 1$ and $\mathrm{TH} 2$ immune responses, respectively. ${ }^{10}$ This activation raises the prospect of novel, lipidbased vaccines and adjuvants. ${ }^{11}$ An analogue of $\alpha$-GalCer, with a truncated sphingosine chain, was recently shown to induce the production predominantly of IL- 4 by NKT cells. ${ }^{12}$ Modification of the lipid chain in the $\alpha$-GalCer structure likely causes immunoactivity switching to demonstrate a profound relationship between structure and activity. ${ }^{13}$

In continuation of our efforts on the development of glycolipids as vaccine adjuvants, we are particularly interested in the study of $\alpha$-GalCer and its analogs. Although a few syntheses of $\alpha$-GalCer have been described, ${ }^{7,14}$ most of previous methods require extensive synthetic steps and the use of expensive starting material for 
synthesizing phytosphingosine, ${ }^{15}$ the lipid moiety of $\alpha$-GalCer. In this article, we report an efficient route for constructing phytosphingosine from commercially available D-lyxose, and several methods for synthesizing $\alpha$-GalCer and its analogs in stereoselective manners.

\section{Result and discussion}

Figure 1 shows a retrosynthetic pathway of $\alpha$-GalCer 1 . The azido group in synthon $\mathbf{3}$ would be reduced to amine, and the obtained galactosyl phytosphingosine can be coupled with appropriate fatty acids to give $\mathbf{1}$ and its analogues, e.g. the short-chain derivative 2 . Phytosphingosine $\mathbf{8}$ in the protected form is a key intermediate that can be obtained by Wittig olefination with the D-lyxose derivative 11, followed by replacement of the $\mathrm{C} 4$ hydroxyl group by an azido group. Execution of this synthetic plan is shown in Scheme 1. The 2,3-dihydroxy groups of D-lyxose were selectively protected as an acetal using 2,2-dimethoxypropane, ${ }^{16}$ and the primary hydroxyl group was subsequently protected as a trityl ether, ${ }^{17}$ giving 11 in $71 \%$ yield. Wittig olefination of 11 using $\mathrm{Ph}_{3} \mathrm{PC}_{13} \mathrm{H}_{27} \mathrm{Br}$ or $\mathrm{Ph}_{3} \mathrm{PC}_{4} \mathrm{H}_{9} \mathrm{Br}$ in the presence of lithium hexamethyldisilazide (LHMDS) ${ }^{18}$ yielded alkenes 12 (93\% yield) and $\mathbf{1 3}$ (85\% yield). The $E / Z$ ratio of $\mathbf{1 2}$ was estimated to be $2: 1$ and $3: 1$ for $\mathbf{1 3}$ according to the ${ }^{1} \mathrm{H}$ NMR spectral analysis. Saturation of double bonds in 12 and $\mathbf{1 3}$ by catalytic hydrogenation afforded 14 and 15, respectively, in 91 and $88 \%$ yields. The hydroxy group in $\mathbf{1 4}$ (or 15) was activated as a triflate, which underwent an $\mathrm{S}_{\mathrm{N}} 2$ reaction with tetramethylguanidinium

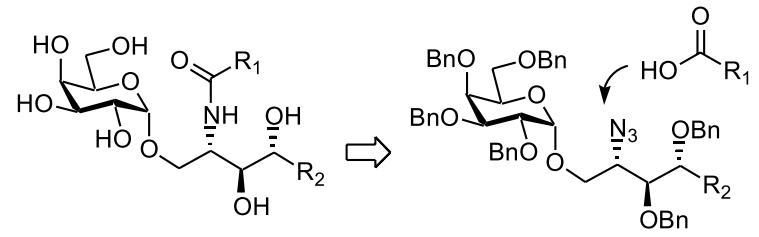

$$
\begin{aligned}
& 1 \mathrm{R}_{1}=\mathrm{C}_{25} \mathrm{H}_{51}, \mathrm{R}_{2}=\mathrm{C}_{14} \mathrm{H}_{29} \\
& 2 \mathrm{R}_{1}=\mathrm{C}_{23} \mathrm{H}_{47}, \mathrm{R}_{2}=\mathrm{C}_{5} \mathrm{H}_{11}
\end{aligned}
$$

$$
\begin{aligned}
& 3 \mathrm{R}_{1}=\mathrm{C}_{25} \mathrm{H}_{51}, \mathrm{R}_{2}=\mathrm{C}_{14} \mathrm{H}_{29} \\
& 4 \mathrm{R}_{1}=\mathrm{C}_{23} \mathrm{H}_{47}, \mathrm{R}_{2}=\mathrm{C}_{5} \mathrm{H}_{11}
\end{aligned}
$$
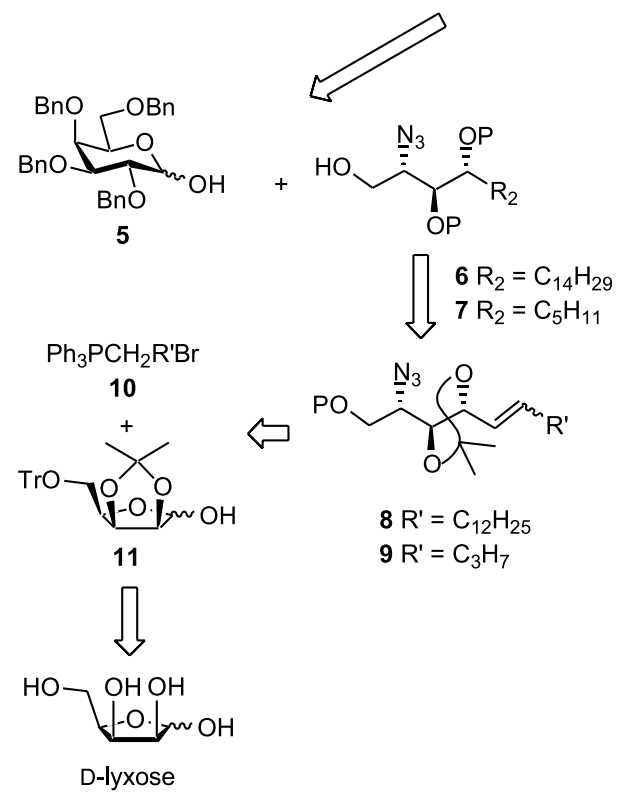

Figure 1. Retro-synthesis of $\alpha$-GalCer (1) and a short-chain analogue 2.

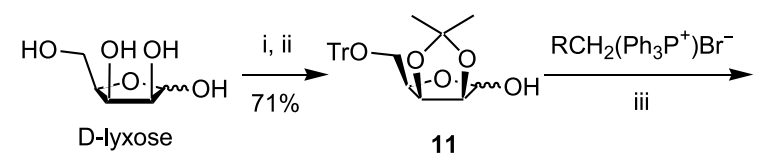<smiles>[R]/C=C\[C@H](O[C@@H](O)[C@H](O)CO)[C@H](O)C(C)(C)C</smiles>

$12 \mathrm{R}=\mathrm{C}_{12} \mathrm{H}_{25}(93 \%)$ $13 \mathrm{R}=\mathrm{C}_{3} \mathrm{H}_{7} \quad(85 \%)$<smiles>[R]C1OC(C)(C)O[C@@H]1[C@H](N)CO[3H]</smiles>

$16 \mathrm{R}=\mathrm{C}_{14} \mathrm{H}_{29} \quad(73 \%)$ $17 \mathrm{R}=\mathrm{C}_{5} \mathrm{H}_{11} \quad(65 \%)$

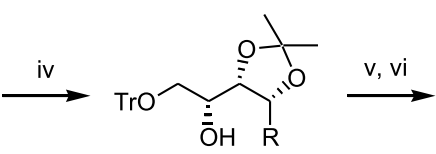

$14 \mathrm{R}=\mathrm{C}_{14} \mathrm{H}_{29}(91 \%)$

$15 \mathrm{R}=\mathrm{C}_{5} \mathrm{H}_{11}(88 \%)$

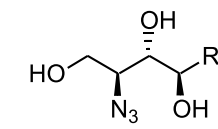

$18 \mathrm{R}=\mathrm{C}_{14} \mathrm{H}_{29}(65 \%)$

$19 \mathrm{R}=\mathrm{C}_{5} \mathrm{H}_{11} \quad(68 \%)$

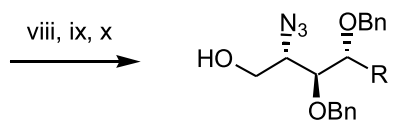

$20 \mathrm{R}=\mathrm{C}_{14} \mathrm{H}_{29}(65 \%)$

$21 \mathrm{R}=\mathrm{C}_{5} \mathrm{H}_{11} \quad(81 \%)$

Scheme 1. Synthesis of phytosphingosind derivatives 20 and 21. Reagents and conditions: (i) 2-methoxypropene, CSA. (ii) $\mathrm{TrCl}$, pyridine, $80^{\circ} \mathrm{C}, 6 \mathrm{~h}$. (iii) LHMDS, THF. (iv) $\mathrm{H}_{2}, \mathrm{Pd}(\mathrm{OH})_{2}$, EtOAc. (v) $\mathrm{Tf}_{2} \mathrm{O}, 2$,6-lutidine, $\mathrm{CH}_{2} \mathrm{Cl}_{2}$. (vi) Tetramethylguanidinium azide. (vii) $\mathrm{AcOH}, \mathrm{MeOH}, 60{ }^{\circ} \mathrm{C}$. (viii) $\mathrm{TrCl}$, pyridine. (ix) $\mathrm{BnBr}, \mathrm{NaH}, \mathrm{DMF}$. (x) $\mathrm{AcOH}, \mathrm{H}_{2} \mathrm{O}$.

azide (TMGA) to give azido compound $\mathbf{1 6}$ (or 17) with inverted configuration. ${ }^{19}$ As attempts of selective removal of the trityl group in $\mathbf{1 6}$ (or 17) failed, simultaneous deprotection $^{15 \mathrm{~b}}$ of the acetal and trityl groups were carried out by treating with acetic acid in $\mathrm{MeOH}$ at $60{ }^{\circ} \mathrm{C}$ to yield triol 18 (or 19). The sphingosine derivatives 20 and 21 suitable to glycosylation were thus prepared from 18 and 19 by a sequence of tritylation, benzylation and de-tritylation. The whole synthetic process took 10 steps to convert D-lyxose into phytosphingosines (20 and 21) in 19\% overall yield.

The benzyl groups were adopted as the protecting groups in both glycosyl acceptors (e.g. 20 and 21) and donors (e.g. 5 and 22) because catalytic hydrogenation can be applied for complete deprotection in the final step to obtain $\alpha$-GalCer $\mathbf{1}$ and its truncated phytosphingosine analogue $\mathbf{2}$ (Scheme 2). Coupling of phtytosphingosine $\mathbf{2 0}$ with galactosyl donor 22 ( $S$-glycoside, $\mathrm{R}=\mathrm{STol}$ ) by using $N$-iodosuccinimide (NIS) and trifluoromethanesulfonic acid $(\mathrm{TfOH})$ as promoters ${ }^{20}$ afforded $\mathbf{3}$ in $93 \%$ yield, albeit in no anomeric selectivity $(\alpha / \beta=1: 1)$. When tetrabenzyl galactose $5(\mathrm{R}=\mathrm{OH})$ was used in dehydrative glycosylation ${ }^{21}$ with $\mathbf{2 0}, 83 \%$ yield of 3 was obtained in a better $\alpha$-selectivity $(\alpha / \beta=3: 1)$. Compound 4 was similarly obtained in $\alpha / \beta=3: 1$ by coupling compound $\mathbf{2 1}$ with $\mathbf{5}$. In principle, the azido and benzyloxyl group can be reduced concurrently. However, reductions by using Raney $\mathrm{Ni}$, Birch reduction and hydrogenation using different catalysts [e.g. $\mathrm{Pd} / \mathrm{C}$ and $\left.\mathrm{Pd}(\mathrm{OH})_{2}\right]$ and various solvents (e.g. EtOAc, $\mathrm{MeOH}$, EtOH and HOAc etc.) under a hydrogen pressure of $1 \mathrm{~atm}$ or $50 \mathrm{~kg} / \mathrm{cm}^{2}$ resulted in complicated mixture. Thus, azide 3 

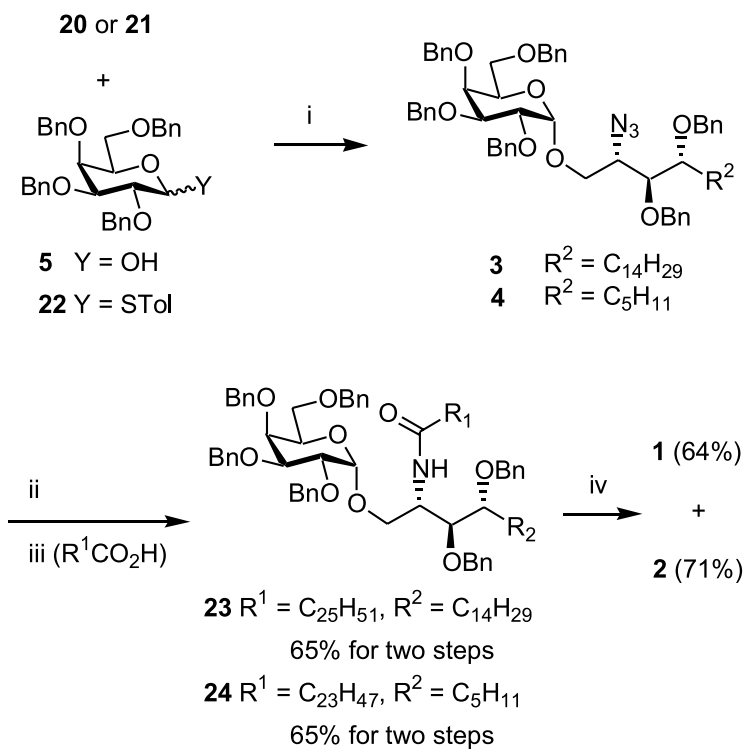

Scheme 2. Synthesis of $\alpha$-GalCer (1) and a short-chain analogue 2 Reagents and conditions: (i) using 5: $\mathrm{Me}_{2} \mathrm{~S}, 2$-Cl-pyridine, $\mathrm{Tf}_{2} \mathrm{O}, \mathrm{CH}_{2} \mathrm{Cl}_{2}$, $4 \AA$ MS; using 22: NIS, TfOH, $\mathrm{CH}_{2} \mathrm{Cl}_{2}, 4 \mathrm{~A}$ MS. (ii) $\mathrm{Ph}_{3} \mathrm{P}$, pyr., $\mathrm{H}_{2} \mathrm{O}, 60^{\circ} \mathrm{C}$, 6 h. (iii) $\mathrm{R}^{1} \mathrm{CO}_{2} \mathrm{H}, \mathrm{EDC}, \mathrm{HOBt}, 20$ h. (iv) $\mathrm{H}_{2}, \mathrm{Pd} / \mathrm{C}, 40 \mathrm{~kg} / \mathrm{cm}^{2}$.

was reduced using Staudinger reaction ${ }^{22}$ to give the amine intermediate, which coupled with hexacosanoic acid by using EDC and HOBT as the promoters to give compound 23 in $65 \%$ yield. The similar reduction of $\mathbf{4}$ and the subsequent coupling reaction with tetracosanoic acid yielded 24. Finally, removal of the benzyl groups culminated in $\alpha$-GalCer $\mathbf{1}$ and the short-chain analogue $\mathbf{2}$.

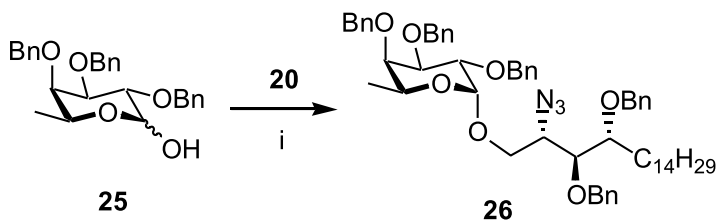

$(70 \%, \alpha / \beta=3: 1)$

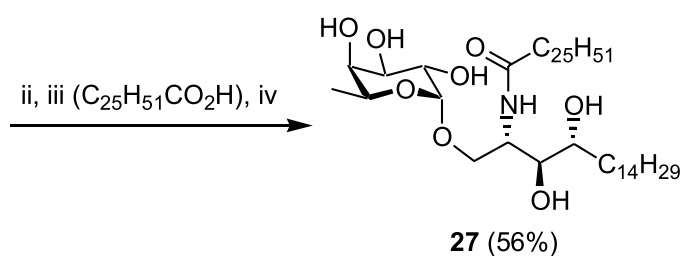

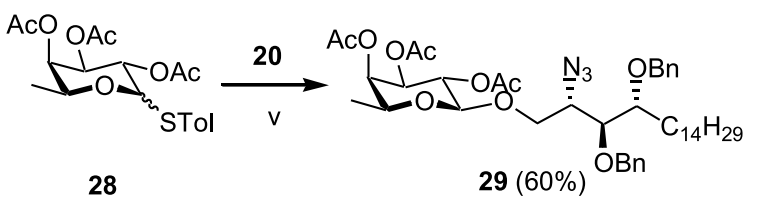

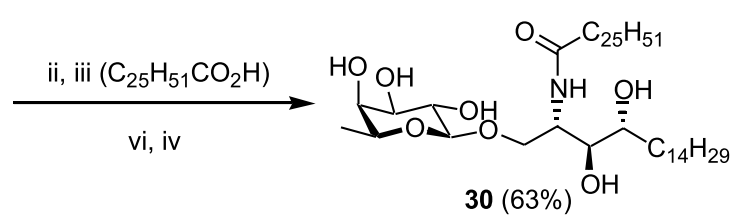

Scheme 3. Synthesis of $\alpha$ - and $\beta$-fucosyl ceramides 27 and 30. Reagents and conditions: (i) $\mathrm{Me}_{2} \mathrm{~S}$, 2-Cl-pyridine, $\mathrm{Tf}_{2} \mathrm{O}, \mathrm{CH}_{2} \mathrm{Cl}_{2}, 4 \AA$ MS. (ii) $\mathrm{Ph}_{3} \mathrm{P}$, pyr., $\mathrm{H}_{2} \mathrm{O}$. (iii) $\mathrm{PyBop}, \mathrm{CH}_{2} \mathrm{Cl}_{2}$. (iv) $\mathrm{H}_{2}, \mathrm{Pd} / \mathrm{C}, 40 \mathrm{~kg} / \mathrm{cm}^{2}$. (v) NIS, TfOH, $4 \AA \mathrm{MS}, \mathrm{CH}_{2} \mathrm{Cl}_{2},-15^{\circ} \mathrm{C}$. (vi) $\mathrm{NaOMe}, \mathrm{MeOH}$.
Fucosyl ceramide does not occur in nature, so the synthesis and examination of the bioactivities of L-fucosyl ceramides (FucCers) 27 and $\mathbf{3 0}$ are of interest. Dehydrative glycosylation of phtytosphingosine 20 with tribenzylfucose $\mathbf{2 5}^{23}$ was performed to give an anomeric mixture of $26(\alpha / \beta=3: 1)$, whereas the coupling reaction with $S$-tolyl triacetylfucoside 28 afforded only $\beta$-anomer 29 (Scheme 3 ). By the procedure similar to that for the synthesis of $\alpha$-GalCer 1 , the $\alpha$-FucCer 27 was synthesized from $\mathbf{2 6}$ in $56 \%$ overall yield by a sequence of azide reduction, amide formation and debenzylation. $\beta$-FucCer 30 was similarly prepared except for removal of the acetyl groups by sodium methoxide in methanol.

Serine-based lipid has been reported to exhibit the similar bioactivity as a ceramide mimic. ${ }^{24}$ It would be interesting to know if serine-based lipid or its amide analogue could mimic the functions of phytosphingosine. In order to pursue the $\alpha$-selective glycosylation with the L-serine derivative $\mathbf{3 5}$, different types of galactosyl donors including sulfide 22, sulfide 31, phosphite 33 and imidate 34 were investigated (Scheme 4). Hydrolysis of sulfide $\mathbf{3 1}$ with NBS in the presence of water, ${ }^{25}$ followed by treatments with $i$ - $\operatorname{Pr}_{2}$ $\mathrm{NP}(\mathrm{OBn})_{2}$ or trichloroacetonitrile according to standard carbohydrate chemistry, gave dibenzyl phosphite $31^{26}$ and trichloroimidate $34,{ }^{27}$ respectively. Glycosylation reactions of 35 generally afforded high yields (89-95\%) of $\mathbf{3 6}$, however, in varied anomeric selectivities depending on the use of different galactosyl donors. ${ }^{26,28}$

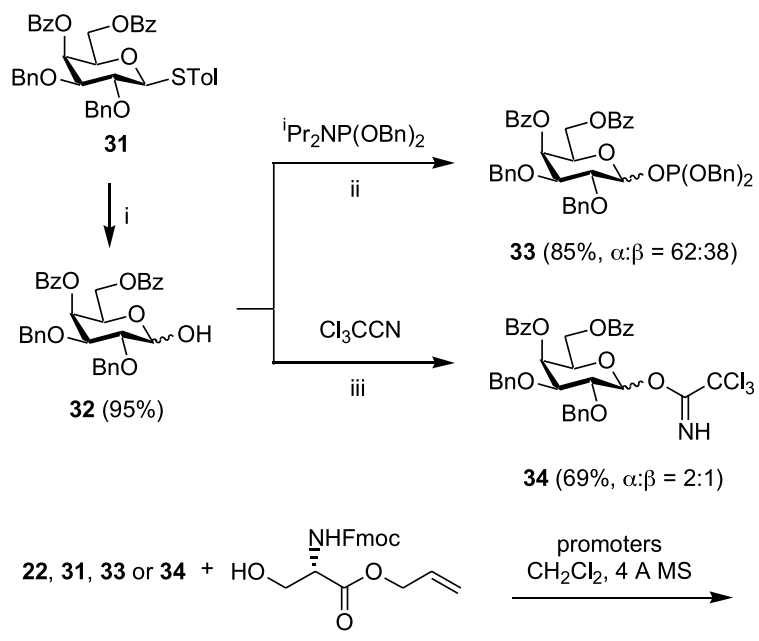

35

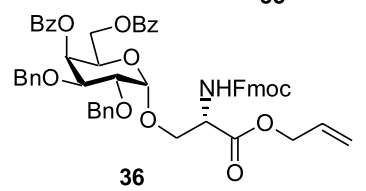

Scheme 4. Synthesis of galactosyl donors and coupling with serine derivative 35. Reagents and conditions: (i) $\mathrm{NBS}, \mathrm{Me}_{2} \mathrm{CO} / \mathrm{H}_{2} \mathrm{O}=9: 1, \mathrm{rt}, 2 \mathrm{~h}$. (ii) $1 H$-tetrazole, THF, rt, $2 \mathrm{~h}$. (iii) DBU, THF, rt, $30 \mathrm{~min}$.

Using tetrabenzyl $S$-galactoside 22, the glycosylation was realized by the promotion of NIS and TfOH to give $\alpha$ and $\beta$-anomers $(2: 1)$ of 36 . The $\alpha / \beta$ selectivity was increased to 9:1 when $S$-galactoside $\mathbf{3 1}$ with benzoate protecting groups at 4- and 6-positions, differing from the benzyl groups in $\mathbf{2 2}$, was applied in the glycosylation. Incorporation of benzoate 
group at 4- or 6-position of galactoside or glucoside, in comparison to benzyl group, is known to enhance the $\alpha$-selectivity of thiotolyl donor. ${ }^{28} \mathrm{We}$ were surprised and fortunate to find that coupling of an $\alpha / \beta$ mixture (6:1) of the phosphite donor $\mathbf{3 1}$ with the serine derivative $\mathbf{3 5}$ in the presence of $\mathrm{TfOH}$ gave only the $\alpha$-glycosylation product 36 in $95 \%$ yield. On the other hand, glycosylation of imidate 34 ( $\alpha$ anomer) in the presence of TMSOTf gave predominantly the $\beta$-anomor of $36(\alpha / \beta=1: 10)$. It was presumed that glycosylation of phosphite donor proceeded with an $\mathrm{S}_{\mathrm{N}}$ 1-like mechanism, whereas that of imidate donor followed an $\mathrm{S}_{\mathrm{N}}$ 2-like pathway. During the glycosylation of phosphite 33, the benzoyl groups at 4- and 6-positions might participate in stabilization of the oxonium intermediate. As the $\beta$-face was blocked, the serine derivative $\mathbf{3 5}$ could only have access to the oxonium intermediate from the $\alpha$-face.

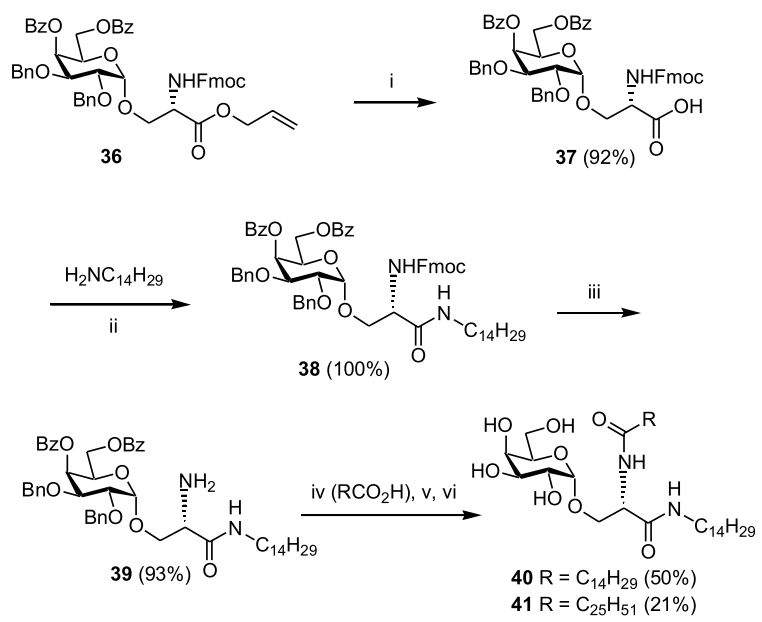

Scheme 5. Synthesis of galactosyl serine-type ceramide analogues $\mathbf{4 0}$ and 41. Reagents and conditions: (i) $\mathrm{Pd}\left(\mathrm{PPh}_{3}\right)_{4}$, THF. (ii) $\mathrm{HBTU}, \mathrm{HOBt}$, $\mathrm{CH}_{2} \mathrm{Cl}_{2}$. (iii) $40 \% \mathrm{H}_{2} \mathrm{NEt} / \mathrm{THF}$. (iv) EDC, $\mathrm{HOBt}$, DMF. (v) $\mathrm{MeONa}$, $\mathrm{MeOH}$. (vi) $\mathrm{H}_{2}, \mathrm{Pd}(\mathrm{OH})_{2}$, EtOH, $\mathrm{CHCl}_{3}, 50 \mathrm{~kg} / \mathrm{cm}^{2}$.
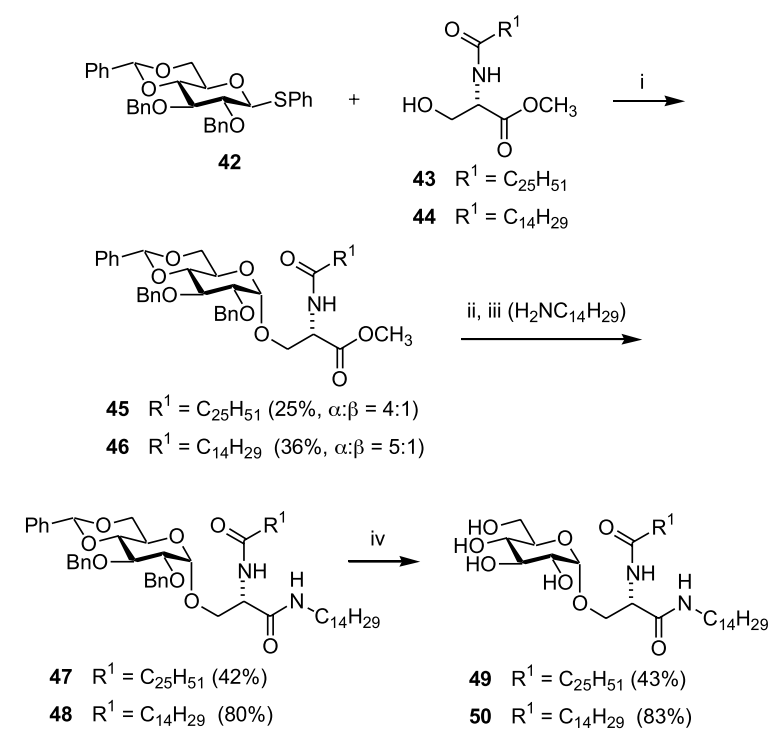

Scheme 6. Synthesis of $\alpha$-glucosyl serine-type ceramides 49 and $\mathbf{5 0 .}$ Reagents and conditions: (i) NIS, cat. TfOH, $4 \AA \mathrm{MS}, \mathrm{CH}_{2} \mathrm{Cl}_{2},-15$ to $-10{ }^{\circ} \mathrm{C}$. (ii) aq. $\mathrm{NaOH}(1 \mathrm{~N})$, THF. (iii) EDC, $\mathrm{HOBT}, \mathrm{CH}_{2} \mathrm{Cl}_{2}$. (iv) $\mathrm{H}_{2}$, $\mathrm{Pd}(\mathrm{OH})_{2} / \mathrm{C}$, cat. AcOH, EtOAc/MeOH (1:1).
As shown in Scheme 5, the allyl group of $\mathbf{3 6}$ was removed by using $\mathrm{Pd}\left(\mathrm{PPh}_{3}\right)_{4}$ catalyst, ${ }^{29}$ and the resulting acid was coupled with 1-tetradecylamine to yield amide 38. Deprotection of the Fmoc group gave amine 39. Amidation of 39 with carboxylic acids, followed by removal of benzoyl and benzyl groups, thus gave $\mathbf{4 0}$ and $\mathbf{4 1}$ with serine-type longchain amide moieties as the structurally simpler mimics of $\alpha$-GalCer.

In order to evaluate the role of $4-\mathrm{OH}$ group of $\alpha$-GalCer in immunoactivity, the $\alpha$-glucosyl serine-type ceramides (e.g. 49 and 50) were prepared. Glycosylation of $S$-glucoside 42 with the $N$-acyl derivatives of methyl L-serine (43 and 44) was carried out by the promotion of NIS and TfOH to give 45 and 46 predominating in the $\alpha$-anomers (Scheme 6). Saponification and amidation of $\mathbf{4 5}$ and $\mathbf{4 6}$ with tetradecylamine, followed by romoval of the benzyl and benzylidene protecting groups, led to the $\alpha$-glucosyl serine-type ceramides 49 and 50. By a similar procedure, the $\alpha$-glucosyl serine-type lipid $\mathbf{5 4}$ was also prepared (Scheme 7).

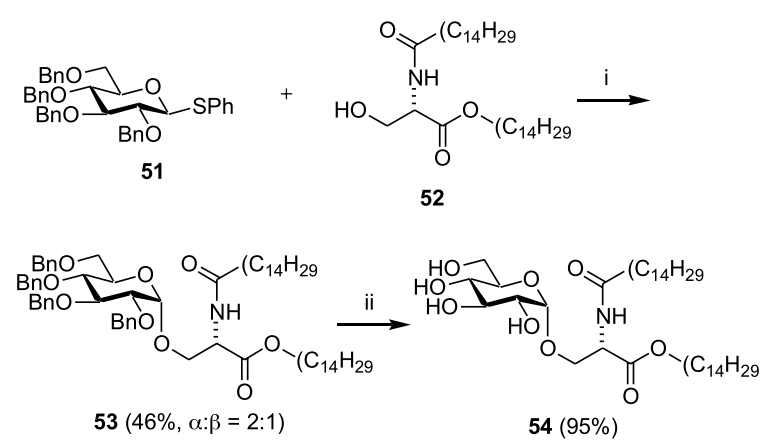

Scheme 7. Synthesis of $\alpha$-glucosyl serine-type ester 54. Reagents and conditions: (i) NIS, cat. TfOH, $4 \AA \mathrm{AS}, \mathrm{CH}_{2} \mathrm{Cl}_{2},-15$ to $-10^{\circ} \mathrm{C}$. (ii) $\mathrm{H}_{2}$, $\mathrm{Pd}(\mathrm{OH})_{2} / \mathrm{C}$, cat. AcOH, EtOAc/MeOH (1:1).

The glycolipids 1, 2, 27, 30, 40, 41, 50 and 54 were submitted to evaluate their activities. First, colorimetric assay using 3-(4,5-dimethylthiazol-2-yl)2,5-diphenyl tetrazolium bromide (MTT) ${ }^{30}$ was conducted to evaluate the proliferation of glycolipid-stimulated mouse spleen cells in the presence of various concentrations of the glycolipids. $\alpha$-GalCer $\mathbf{1}$ and the truncated analog $\mathbf{2}$ at a concentration of $100 \mathrm{ng} / \mathrm{mL}$ significantly promoted the cell proliferation activity comparing to the control samples (Fig. 2). The galactosyl serine-type lipid $\mathbf{4 0}$ at the same concentration also slightly enhanced the cell proliferation activity.

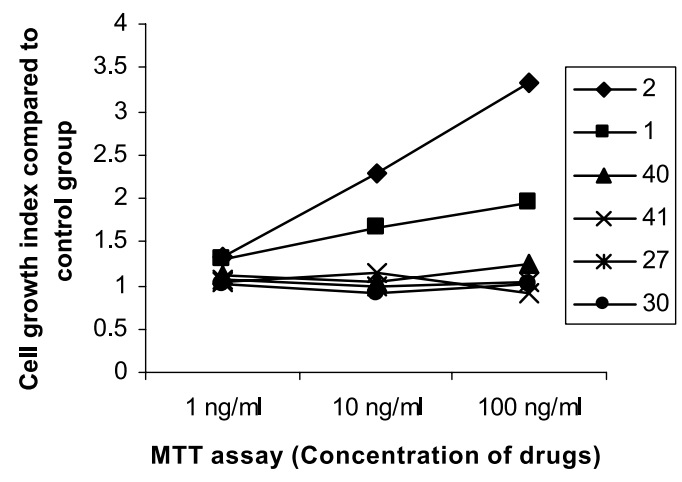

Figure 2. MTT assay for glycolipids 1, 2, 27, 30, 40 and 41. 
The expression levels of the cytokines, IFN- $\gamma$ and IL-4, in mouse spleen cells were determined by an ELISA assay (enzyme-linked immunosorbent assay) ${ }^{31}$ using $100 \mathrm{ng} / \mathrm{mL}$ glycolipids. Only compounds $\mathbf{1}, \mathbf{2}$ and $\mathbf{4 0}$ were observed to stimulate IFN- $\gamma$ and IL-4 expression after $24 \mathrm{~h}$ (Fig. 3). The related long-term cytokine stimulation by $\mathbf{1}$ and $\mathbf{2}$ is shown in Figure 4. Both compounds had similar effect on INF- $\gamma$ production while compound 2 had a stronger effect on IL-4 production. Notably, these results are not the same as that obtained for compounds $\mathbf{1}$ and $\mathbf{2}$ on NKT cells. ${ }^{12}$ The
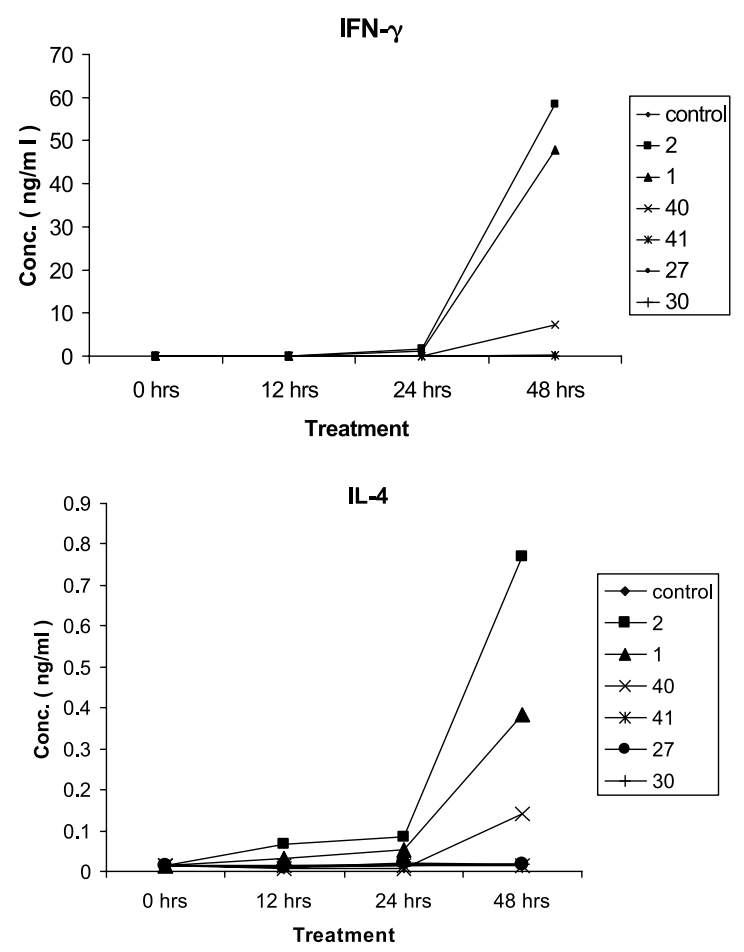

Figure 3. Cytokine assays for $\alpha$-GalCer (1) and other glycolipids. For clarity, the lines of inactive compounds $\mathbf{5 0}$ and $\mathbf{5 4}$ are omitted. Untreated cells are taken as the control.
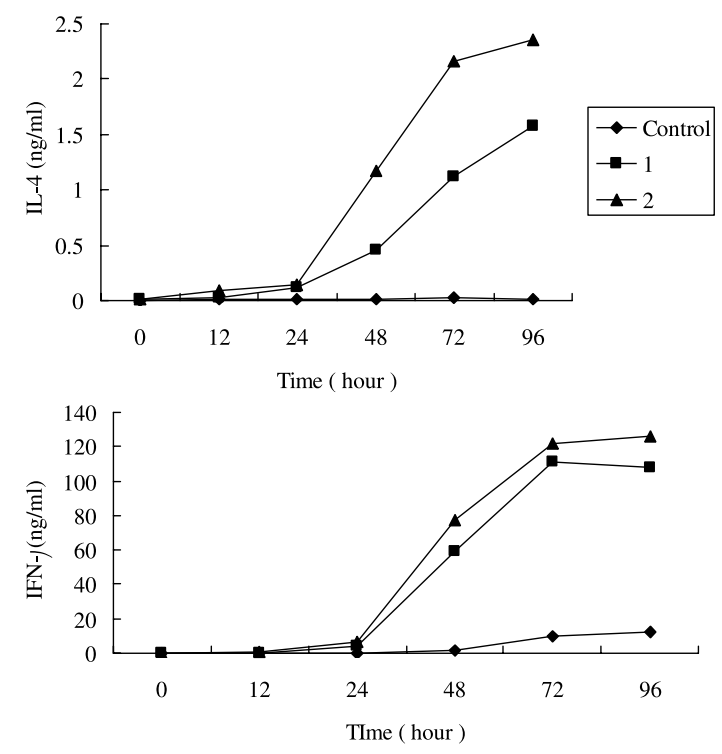

Figure 4. Long-term cytokine assays for $\alpha$-GalCer (1) and a short-chain analogue 2 using untreated cells as the control. simplified $\alpha$-GalCer analog $\mathbf{4 0}$, having a serine-type lipid to replace phytosphingosine, still retained some immunoactivity. Although compounds $\mathbf{1}$ and $\mathbf{2}$ are better antigens to stimulate the production of cytokines, compound $\mathbf{4 0}$ has the advantage of simple synthesis. The fucosyl ceramides (27 and 30) and glucosyl serine-type lipids (50 and 54) did not show any immuno-activity.

In conclusion, we have devised an expedient method for the synthesis of glycosphingolipids, starting from an inexpensive sugar, D-lyxose. We have also carried out the syntheses of galactosyl, fucosyl and glucosyl ceramides in $\alpha$-anomeric selectivity. The bioassays indicated that $\alpha$-galactosyl ceramides $\mathbf{1}$ and $\mathbf{2}$ exhibited substantial effects on the proliferation of mouse splenocytes as well as the expression of cytokines IFN- $\gamma$ and IL-4. The galactosyl serine-type ceramide $\mathbf{4 0}$ also showed similar bioactivities, though to less degrees. Works on the synthesis of a glycolipid library and extensive evaluation of the immuno-modulating activities of these immuno-stimulators are in progress.

\section{Experimental}

Compounds $1,{ }^{32} \mathbf{3}^{33}{ }^{33},{ }^{34} \mathbf{1 1},{ }^{35} \mathbf{1 8},{ }^{15 \mathrm{a}} \mathbf{1 9},{ }^{15 \mathrm{a}} \mathbf{2 0},{ }^{36} \mathbf{2 2},{ }^{20} \mathbf{2 3},{ }^{35}$ $\mathbf{2 5},{ }^{37} \mathbf{2 8},{ }^{38} \mathbf{3 5},{ }^{39} \mathbf{4 2}^{40}$ and $\mathbf{5 1}^{41}$ have previously been reported, and our prepared samples showed consistent ${ }^{1} \mathrm{H}$ and ${ }^{13} \mathrm{C}$ NMR spectral data to the structural assignments.

\subsection{Representative procedure for glycosylation. Using aldose $(\operatorname{method} \mathbf{A})$}

To a solution of galactosyl donor 5 (300 $\mathrm{mg}, 0.57 \mathrm{mmol})$, dimethylsulfide $(54 \mu \mathrm{L}, 0.74 \mathrm{mmol}), 4 \AA$ molecular sieve $(100 \mathrm{mg})$ and 2-chloropyridine $(150 \mu \mathrm{L}, 1.58 \mathrm{mmol})$ in anhydrous $\mathrm{CH}_{2} \mathrm{Cl}_{2}(2 \mathrm{~mL})$ under $\mathrm{Ar}$ at $-45^{\circ} \mathrm{C}$ was added trifluoromethanesulfonic anhydride $(94 \mu \mathrm{L}, 0.56 \mathrm{mmol})$. The reaction mixture was stirred for $20 \mathrm{~min}$ at $0{ }^{\circ} \mathrm{C}$ and $20 \mathrm{~min}$ at room temperature. Phytosphingosin derivative $\mathbf{2 1}$ (150 mg, $0.37 \mathrm{mmol})$ in $\mathrm{CH}_{2} \mathrm{CL}_{2}(2 \mathrm{~mL})$ was slowly added via cannula under positive nitrogen pressure. The reaction mixture was stirred at room temperature for $20 \mathrm{~h}$, and then filtered. The crude filtrate was partitioned between EtOAc and water. The organic layer was separated, washed with brine, dried over $\mathrm{MgSO}_{4}$, and concentrated under reduced pressure. The residue was chromatographed on a silica gel column (EA/Hex from 9:1 to 4:1) to give the product $\mathbf{4}$ as yellow oil $(285 \mathrm{mg}, 82 \%)$.

\subsection{Using glycosyl sulfide (method B)}

To a mixture of glycosyl sulfide 28 (200 $\mathrm{mg}, 0.5 \mathrm{mmol}$ ), phytosphingosin derivative $20(220.2 \mathrm{mg}, 0.42 \mathrm{mmol})$ and $4 \mathrm{~A}$ molecular sieves $(400 \mathrm{mg})$ in $\mathrm{CH}_{2} \mathrm{Cl}_{2}(2.5 \mathrm{~mL})$ was added NIS (453.6 mg, $2.0 \mathrm{mmol})$ at $0{ }^{\circ} \mathrm{C}$ under Ar. The reaction mixture was stirred for $30 \mathrm{~min}$, and $\mathrm{TfOH}(1.9 \mu \mathrm{L}$, $0.02 \mathrm{mmol}$ ) was added. After $30 \mathrm{~min}$, the reaction mixture was concentrated under reduced pressure. The residue was diluted with EtOAc, and washed with aqueous $\mathrm{Na}_{2} \mathrm{~S}_{2} \mathrm{O}_{3}$, saturated $\mathrm{NaHCO}_{3}$ and brine. The organic phase was dried over $\mathrm{MgSO}_{4}$, and concentrated under reduced pressure. The 
residue was chromatographed on a silica gel column (EtOAc/hexane, 1:2) to give product 29 (200.0 mg, 60\%).

\subsection{Using glycosyl phosphite (method $C)$}

A mixture of serine derivative $35(0.55 \mathrm{~g}, 1.5 \mathrm{mmol})$, galactosyl phosphite $33(\alpha / \beta=6 / 1,1.33 \mathrm{~g}, 1.6 \mathrm{mmol})$ and $4 \AA$ molecular sieves in dried $\mathrm{CH}_{2} \mathrm{H}_{2}(20 \mathrm{~mL})$ was stirred for $10 \mathrm{~min}$ at room temperature under Ar. Trifluoromethanesulfonic acid $(26 \mu \mathrm{L}, 0.3 \mathrm{mmol})$ was added, and the mixture was stirred at room temperature for another $1 \mathrm{~h}$. In this period of reaction, compound $\mathbf{3 5}$ was completely consumed as shown by TLC analysis. The reaction mixture was filtered through a short pad of Celite. The filtrate was diluted with $\mathrm{CH}_{2} \mathrm{Cl}_{2}$, and washed with saturated aqueous $\mathrm{NaHCO}_{3}$ and brine. The organic layer was dried over $\mathrm{Na}_{2} \mathrm{SO}_{4}$, and concentrated under reduced pressure. The residue was chromatographed on a silica gel column (EtOAc/Hex: from 8:1 to 3:1) to obtain the product 36 $(\alpha$-anomer) as yellow oil $(1.30 \mathrm{~g}, 95 \%)$.

\subsection{Representative procedure for Wittig reaction}

To a mixture of triphenyl-tridecyl-phosphonium bromide $(4.86 \mathrm{~g}, 9.2 \mathrm{mmol})$ in anhydrous THF $(20 \mathrm{~mL})$ was added lithium hexamethyldisilazide (LHMDS, $9.2 \mathrm{~mL}$ of $1 \mathrm{M}$ solution in THF) at $0{ }^{\circ} \mathrm{C}$ under $\mathrm{Ar}$, and stirred at $0{ }^{\circ} \mathrm{C}$ for $60 \mathrm{~min}$. A solution of $\mathbf{1 1}^{34}(2.0 \mathrm{~g}, 4.6 \mathrm{mmol})$ in anhydrous THF (10 mL) was treated with LHMDS $(4.6 \mathrm{~mL}, 4.6 \mathrm{mmol})$ at $0{ }^{\circ} \mathrm{C}$ for $60 \mathrm{~min}$ under $\mathrm{Ar}$ to give the 11-anion solution. The mixture of the above prepared phosphonium solution and 11-anion solution was stirred at $0{ }^{\circ} \mathrm{C}$ to room temperature for $9 \mathrm{~h}$, and then quenched with $\mathrm{MeOH}$. After removal of volatiles under reduced pressure, the residue was partitioned between EtOAc and water. The organic layer was separated, washed with brine, dried over anhydrous $\mathrm{MgSO}_{4}$, and concentrated under reduced pressure. The residue was chromatographed on a silica gel column (EtOAc/hexane, 9:1 to 3:1) to give the product 12 as colorless oil $(2.58 \mathrm{~g}, 93 \%)$. The $E / Z$ ratio is about $2: 1$ as determined by the ${ }^{1} \mathrm{H}$ NMR analysis.

\subsection{Representative procedure for catalytic hydrogenation}

To a solution of compound $24(40 \mathrm{mg}, 0.032 \mathrm{mmol})$ in a cosolvent system of $\mathrm{CHCl}_{3}$ and $\mathrm{EtOH}(1: 4,1 \mathrm{~mL})$ was added $\mathrm{Pd} / \mathrm{C}(10 \mathrm{mg})$. The reaction was shaken under high pressure of hydrogen $\left(50 \mathrm{~kg} / \mathrm{cm}^{2}\right)$ for $6 \mathrm{~h}$. The reaction mixture was filtered over a short pad of Celite, and the filtercake was washed with $\mathrm{CH}_{2} \mathrm{Cl}_{2} / \mathrm{MeOH}$ cosolvent (1:1). The filtrate was concentrated under reduced pressure, and the resulting residue was purified by $\mathrm{LH} 20(\mathrm{MeOH} /$ $\left.\mathrm{CHCl}_{3}=1: 1\right)$ and then silica gel chromatography $(\mathrm{MeOH} /$ $\mathrm{CHCl}_{3}=1: 15$ ) to give the product 2 as white solid (16 mg, $71 \%)$.

\subsection{Representative procedure for substitution of hydroxyl group by azide}

To a mixture of 14 (91 mg, $0.15 \mathrm{mmol}), 2,6$-lutidine $(21 \mu \mathrm{L}$, $0.18 \mathrm{mmol})$ and $4 \AA$ molecular sieves $(30 \mathrm{mg})$ in anhydrous $\mathrm{CH}_{2} \mathrm{Cl}_{2}(0.5 \mathrm{~mL})$ under $\mathrm{Ar}$ at $-40^{\circ} \mathrm{C}$ was added trifluoromethanesulfonic anhydride $(30 \mu \mathrm{L}, 0.18 \mathrm{mmol})$. After stirring at $-40{ }^{\circ} \mathrm{C}$ for $30 \mathrm{~min}$, tetramethylguanidinium azide ( $71 \mathrm{mg}, 0.45 \mathrm{mmol}$ ) was added in one portion, and the reaction mixture was slowly warmed to room temperature and stirred for $18 \mathrm{~h}$. The mixture was filtered over a short pad of Celite, and the filtrate was partitioned between EtOAc and water. The organic layer was separated, washed with brine, dried over anhydrous $\mathrm{MgSO}_{4}$, and concentrated under reduced pressure. The residue was chromatographed on a silica gel column to give product $\mathbf{1 6}$ as colorless oil (76 mg, 73\%).

\subsection{Representative procedure for azide reduction and amide formation}

To a solution of compound $4(100 \mathrm{mg}, 0.11 \mathrm{mmol})$ in pyridine $(4 \mathrm{~mL})$ and water $(0.4 \mathrm{~mL})$ cosolvent system was added triphenylphosphine $(57 \mathrm{mg}, 0.22 \mathrm{mmol})$. The reaction mixture was heated to $40{ }^{\circ} \mathrm{C}$ for $12 \mathrm{~h}$, concentrated, and the residue was partitioned between EtOAc and water. The organic layer was separated, washed with brine, dried over anhydrous $\mathrm{MgSO}_{4}$, and concentrated. The crude amine product was used for the next step without further purification.

To a solution of the crude amine product and tetracosanoic acid (53 mg, $0.14 \mathrm{mmol}$ ) in dried DMF (1 mL) was added triethylamine $(30 \mu \mathrm{L}, \quad 0.22 \mathrm{mmol}), \quad$ EDC $\quad(33 \mathrm{mg}$, $0.17 \mathrm{mmol})$ and $\mathrm{HOBt}(23 \mathrm{mg}, 0.17 \mathrm{mmol})$ at $0{ }^{\circ} \mathrm{C}$ under Ar. The reaction mixture was stirred at $0{ }^{\circ} \mathrm{C}$ to room temperature for $12 \mathrm{~h}$, and then concentrated. The residue was partitioned between EtOAc and water. The organic layer was separated, washed with brine, dried over $\mathrm{MgSO}_{4}$, and concentrated under reduced pressure. The residue was chromatographed on a silica gel column (EA/Hex $=1: 19$ to 1:9) to give the desired product $\mathbf{2 4}$ as white foam (88 $\mathrm{mg}$, $65 \%$ in two steps).

\subsection{Preparation of spleen cells}

Male BALB/c mice about 8-weeks-old were sacrificed and the spleen cells were isolated. Briefly, spleen cells were aseptically prepared by mechanical disruption and red blood cells were removed by ACK lysis buffer $\left(\mathrm{NH}_{4} \mathrm{Cl}\right.$ $150 \mathrm{mM}, \mathrm{KHCO}_{3} 1 \mathrm{mM}$, EDTA $0.1 \mathrm{mM}$ ) treatment. Viable cells were washed with PBS saline, then counted and resuspended in RPMI-1640 supplemented with $50 \mu \mathrm{M}$ 2-mercaptoethanol, $10 \mathrm{mM}$ HEPES, $2 \mathrm{mM}$ L-glutamine and $10 \%$ FCS.

MTT assay. Spleen cell solution $\left(100 \mu \mathrm{L}\right.$ of $2.5 \times 10^{6}$ cell/mL containing 1,10 and $100 \mathrm{ng} / \mathrm{mL}$ of test compound or vehicle DMSO only) were dispensed into 96-well plate and cultured at $37{ }^{\circ} \mathrm{C}$ incubator containing $5 \% \mathrm{CO}_{2}$ for two days. After cultured, $20 \mu \mathrm{L}$ of MTT stock solution ( $5 \mathrm{mg} / \mathrm{mL}$ dissolved in PBS and filtered) was added to the cultured cells and then incubated the cells for a further $4 \mathrm{~h}$. For dissolving the dark blue formazan product (converted from MTT in active mitochondria), $120 \mu \mathrm{L}$ of $0.04 \mathrm{~N} \mathrm{HCl}$ in isopropyl alcohol was added to each wells. The colorimetric values were measured by microtiter plate reader with filter settings of 570 and $630 \mathrm{~nm}$ as reference. The cell growth index was calculated by the following formula: cell growth 
index $=\left(\right.$ value $_{(\text {test }}$ compounds $)-$ value $\left._{(\text {blank })}\right) /\left(\right.$ value $_{(\text {control })}-$ value $\left.\left._{(\text {blank })}\right)\right) \times 100$. The value $_{(\text {control })}$ was the detected value of the cells cultured with medium containing vehicle, while the $\operatorname{value}_{\text {(blank) }}$ was that of medium only.

\subsection{Cytokine assay}

Spleen cells were suspended in RPMI-1640 medium containing $10 \%$ FCS in cell density of $5 \times 10^{6}$ cells $/ \mathrm{mL}$. The cell solution was added test compound to a final concentration of $100 \mathrm{ng} / \mathrm{mL}$ or none as control and was dispensed $200 \mu \mathrm{L} /$ well into 96-well plate. The culture plates were incubated at $37^{\circ} \mathrm{C}$ incubator containing $5 \% \mathrm{CO}_{2}$ for 0 , 12, 24 and $48 \mathrm{~h}$. At each time point, the culture supernatant was drawn for IFN- $\gamma$ and IL-4 detection using standard sandwich ELISA. All procedures were conducted according to the standard protocol of the assay kits from Quantikine ${ }^{\circledR}$ M. (catalog number was MIF00 for INF- $\gamma$ and M4000 for IL-4).

3.9.1. $(2 S, 3 S, 4 R)-1-O$-( $\alpha$-D-Galactopyranosyl)-2-( $N$-tetracosanoylamino)-1,3,4-nonanetriol (2). ${ }^{1} \mathrm{H} \quad \mathrm{NMR}$ $\left(400 \mathrm{MHz}\right.$, pyridine- $\left.d_{5}\right) \delta 0.82(\mathrm{t}, J=7.2 \mathrm{~Hz}, 3 \mathrm{H}), 0.89(\mathrm{t}$, $J=6.8 \mathrm{~Hz}, 3 \mathrm{H}), 1.10-1.50(\mathrm{br}, 46 \mathrm{H}), 1.58-1.70(\mathrm{~m}, 1 \mathrm{H})$, $1.78-1.94(\mathrm{~m}, 3 \mathrm{H}), 2.46(\mathrm{t}, J=7.4 \mathrm{~Hz}, 2 \mathrm{H}), 4.28-4.34$ $(\mathrm{m}, 2 \mathrm{H}), 4.36-4.47(\mathrm{~m}, 3 \mathrm{H}), 4.52(\mathrm{t}, J=5.6 \mathrm{~Hz}, 1 \mathrm{H}), 4.56$ $(\mathrm{d}, J=3.2 \mathrm{~Hz}, 1 \mathrm{H}), 4.63-4.72(\mathrm{~m}, 2 \mathrm{H}), 5.27(\mathrm{~m}, 1 \mathrm{H}), 5.58$ $(\mathrm{d}, J=3.6 \mathrm{~Hz}, 1 \mathrm{H}), 8.47(\mathrm{~d}, J=8.4 \mathrm{~Hz}, 1 \mathrm{H}) .{ }^{13} \mathrm{C} \mathrm{NMR}$ $\left(100 \mathrm{MHz}\right.$, pyridine- $\left.d_{5}\right) \delta 14.7,23.4,23.5,26.6,26.9,30.1$, 30.2 , 30.3, 30.5, 32.6, 32.9, 34.8, 37.3, 51.9, 63.1, 69.1, $70.2,71.5,72.1,72.9,73.5,77.2,102.0,173.7$. HRMS (MALDI-TOF, $\mathrm{M}+\mathrm{H}^{+}$) calcd for $\mathrm{C}_{39} \mathrm{H}_{78} \mathrm{NO}_{9}$ : 704.5677 . Found: 704.5663 .

3.9.2. $(2 S, 3 S, 4 R)-1-O$-( $\alpha$-L-Fucopyranosyl)-2-( $N$-hexacosanoylamino)-1,3,4-octadecanetriol (27). ${ }^{1} \mathrm{H}$ NMR $\left(\mathrm{CDCl}_{3} / \mathrm{MeOH}=1 / 1,400 \mathrm{MHz}\right): \delta 0.86(\mathrm{t}, 6 \mathrm{H}, J=$ $6.8 \mathrm{~Hz}), 1.21(\mathrm{~d}, 3 \mathrm{H}, J=6.4 \mathrm{~Hz}), 1.25(\mathrm{~m}, 72 \mathrm{H}), 2.19(\mathrm{t}$, $2 \mathrm{H}, J=7.6 \mathrm{~Hz}), 3.41(\mathrm{dd}, 1 \mathrm{H}, J=3.6,10.0 \mathrm{~Hz}), 3.46-3.53$ $(\mathrm{m}, 1 \mathrm{H}), 3.59-3.62(\mathrm{~m}, 1 \mathrm{H}), 3.65-3.76(\mathrm{~m}, 2 \mathrm{H}), 3.72(\mathrm{dd}$ $1 \mathrm{H}, J=3.6,6.8 \mathrm{~Hz}), 3.95-3.97(\mathrm{~m}, 2 \mathrm{H}), 4.17-4.19(\mathrm{~m}, 1 \mathrm{H})$, $4.74(\mathrm{~d}, 1 \mathrm{H}, J=3.6 \mathrm{~Hz}) .{ }^{13} \mathrm{C} \mathrm{NMR}\left(\mathrm{CDCl}_{3}, 400 \mathrm{MHz}\right): \delta$ $13.0,15.1,21.9,25.3,28.7,28.7,28.9,28.9,29.0,31.2$, 63.5, 65.7, 66.7, 68.2, 69.6, 69.9, 71.5, 71.6, 98.6, 173.8. HRMS (MALDI-TOF, $\mathrm{M}+\mathrm{Na}^{+}$) calcd for $\mathrm{C}_{50} \mathrm{H}_{99} \mathrm{NO}_{8} \mathrm{Na}$ : 864.7268 , found 864.7252 .

3.9.3. $(2 S, 3 S, 4 R)-1-O$-( $\beta$-L-Fucopyranosyl)-2-( $N$-hexacosanoylamino)-1,3,4-octadecanetriol (30). ${ }^{1} \mathrm{H}$ NMR $\left(\mathrm{CDCl}_{3} / \mathrm{MeOH}=1 / 1,400 \mathrm{MHz}\right) \delta 0.87(\mathrm{t}, 6 \mathrm{H}, J=6.8 \mathrm{~Hz})$, $1.25-1.28(\mathrm{~m}, 75 \mathrm{H}), 2.19(\mathrm{t}, 2 \mathrm{H}, J=7.6 \mathrm{~Hz}), 3.45-3.49(\mathrm{~m}$, $3 \mathrm{H}), 3.56-3.63(\mathrm{~m}, 2 \mathrm{H}), 3.67(\mathrm{dd}, 1 \mathrm{H}, J=5.2,7.2 \mathrm{~Hz})$, 3.87-3.88 (m, 2H), 4.07-4.11 (m, 1H), $4.23(\mathrm{~d}, 1 \mathrm{H}, J=$ $7.2 \mathrm{~Hz}) .{ }^{13} \mathrm{C} \mathrm{NMR}\left(\mathrm{CDCl}_{3}, 500 \mathrm{MHz}\right) \delta 12.9,15.1,21.8$, $25.1,25.2,28.5,28.6,28.6,28.7,28.8,28.9,28.9,29.0$, 31.1, 35.7, 49.8, 68.4, 70.2, 70.4, 71.0, 71.6, 73.1, 73.3, 102.9, 174.1. HRMS (MALDI-TOF, $\mathrm{M}+\mathrm{H}^{+}$) calcd for $\mathrm{C}_{50} \mathrm{H}_{100} \mathrm{NO}_{8}$ : 842.7449, found 842.7440.

3.9.4. Pentadecanoic acid [1-tetradecylcarbamoyl-2-( $\alpha$ D-galactopyranosyl)-ethylamide (40). ${ }^{1} \mathrm{H} \quad \mathrm{NMR}$ (400 MHz, pyridine- $\left.d_{5}\right) \delta 0.87(\mathrm{t}, J=6.6 \mathrm{~Hz}, 6 \mathrm{H}), 1.14$ 1.48 (br, 44H), 1.56-1.68 (m, 2H), 1.72-1.85 (m, 2H), 2.47 (t, $J=7.4 \mathrm{~Hz}, 2 \mathrm{H}), 3.47(\mathrm{dd}, J=6.8,12.8 \mathrm{~Hz}, 2 \mathrm{H}), 4.26(\mathrm{dd}$, $J=7.4,10.6 \mathrm{~Hz}, 1 \mathrm{H}), 4.35-4.52(\mathrm{~m}, 4 \mathrm{H}), 4.55(\mathrm{t}, J=5.8 \mathrm{~Hz}$, $1 \mathrm{H}), 4.60(\mathrm{~d}, J=3.2 \mathrm{~Hz}, 1 \mathrm{H}), 4.68(\mathrm{dd}, J=3.8,9.8 \mathrm{~Hz}, 1 \mathrm{H})$, $5.35(\mathrm{dt}, J=5.2,7.4 \mathrm{~Hz}, 1 \mathrm{H}), 5.56(\mathrm{~d}, J=3.6 \mathrm{~Hz}, 1 \mathrm{H}), 8.85$ $(\mathrm{t}, J=5.4 \mathrm{~Hz}, 1 \mathrm{H}) .{ }^{13} \mathrm{C} \mathrm{NMR}\left(100 \mathrm{MHz}\right.$, pyridine- $\left.d_{5}\right) \delta$ $14.7,23.4,26.6,27.80,30.1,30.1,30.1,30.3,30.4,32.6$, 37.0, 40.4, 53.8, 63.2, 70.1, 70.7, 71.5, 72.01, 73.7, 102.0, 171.3, 173.8. HRMS (MALDI-TOF, $\mathrm{M}+\mathrm{H}^{+}$) calcd for $\mathrm{C}_{38} \mathrm{H}_{75} \mathrm{~N}_{2} \mathrm{O}_{8}$ : 687.5523. Found: 687.5527 .

3.9.5. $O$-( $\alpha$-D-Glucopyranosyl)- $N$-pentadecanoyl-L-serine tetradecyl amide (50). TLC $\left(\mathrm{MeOH} / \mathrm{CHCl}_{3}=1: 10\right) R_{\mathrm{f}}$ $0.15 ;{ }^{1} \mathrm{H}$ NMR ( $\left.\mathrm{CD}_{3} \mathrm{OD}, 400 \mathrm{MHz}\right) \delta 4.86(1 \mathrm{H}, \mathrm{H}-1$, mixed with water peak), $4.56(1 \mathrm{H}, \mathrm{dd}, J=6.2,5.9 \mathrm{~Hz}, \mathrm{H}-2)$, $3.88\left(1 \mathrm{H}, \mathrm{dd}, J=10.5,6.2 \mathrm{~Hz}, \mathrm{H}-1^{\prime}\right), 3.85(1 \mathrm{H}, \mathrm{dd}, J=11.8$, $2.4 \mathrm{~Hz}, \mathrm{H}-6), 3.78$ (1H, dd, $\left.J=10.5,5.9 \mathrm{~Hz}, \mathrm{H}-1^{\prime}\right), 3.70$ $(1 \mathrm{H}, \mathrm{dd}, J=11.8,5.6 \mathrm{~Hz}, \mathrm{H}-6), 3.63(1 \mathrm{H}, \mathrm{dd}, J=9.7$, $9.2 \mathrm{~Hz}, \mathrm{H}-3), 3.58$ (1H, ddd, $J=9.9,5.6,2.4 \mathrm{~Hz}, \mathrm{H}-5), 3.45$ $(1 \mathrm{H}, \mathrm{dd}, J=9.7,3.8 \mathrm{~Hz}, \mathrm{H}-2), 3.32(1 \mathrm{H}, \mathrm{dd}, J=9.9,9.2 \mathrm{~Hz}$, $\mathrm{H}-4), 3.26-3.21\left(2 \mathrm{H}, \mathrm{m}, \mathrm{H}-3^{\prime}\right), 2.30(2 \mathrm{H}, \mathrm{t}, J=7.5 \mathrm{~Hz}$, $\left.\mathrm{H}-4^{\prime}\right), 1.67-1.64(2 \mathrm{H}, \mathrm{m}), 1.57-1.54(2 \mathrm{H}, \mathrm{m}), 1.50-1.10$ (44H, br), $0.94\left(6 \mathrm{H}, \mathrm{t}, \mathrm{CH}_{3} \times 2\right) ;{ }^{13} \mathrm{C} \mathrm{NMR}\left(\mathrm{CD}_{3} \mathrm{OD}\right.$, $100 \mathrm{MHz}) \delta 176.4,172.2,101.0,75.2,74.2,73.6,71.8,69.1$, $62.8,54.9,40.8,37.0,33.2,31.0,30.9,30.9,30.8,30.7$, $30.6,30.6,30.5,28.2,27.0,23.9,14.6$; FAB-MS $m / z 687.5$ $\left(\mathrm{M}^{+}+1\right)$; HRMS calcd. for $\mathrm{C}_{38} \mathrm{H}_{75} \mathrm{~N}_{2} \mathrm{O}_{8}\left(\mathrm{M}^{+}+\mathrm{H}\right)$ 687.5523, Found: 687.5531.

3.9.6. $O$-( $\alpha$-D-Glucopyranosyl)- $N$-pentadecanoyl-L-serine tetradecyl ester (54). TLC $\left(\mathrm{MeOH} / \mathrm{CHCl}_{3}=1 / 7\right) R_{\mathrm{f}} 0.33$; ${ }^{1} \mathrm{H}$ NMR $\left(\mathrm{CD}_{3} \mathrm{OD}, 400 \mathrm{MHz}\right) \delta 4.83(1 \mathrm{H}, \mathrm{d}, J=3.8 \mathrm{~Hz}$, $\mathrm{H}-1), 4.69$ (1H, dd, $\left.J=5.6,4.4 \mathrm{~Hz}, \mathrm{H}-2^{\prime}\right), 4.18(2 \mathrm{H}, \mathrm{t}, J=$ $\left.6.6 \mathrm{~Hz}, \mathrm{H}-3^{\prime}\right), 3.99\left(1 \mathrm{H}, \mathrm{dd}, J=10.8,4.4 \mathrm{~Hz}, \mathrm{H}-1^{\prime}\right), 3.95$ $\left(1 \mathrm{H}, \mathrm{dd}, J=10.8,5.6 \mathrm{~Hz}, \mathrm{H}-1^{\prime}\right), 3.84(1 \mathrm{H}, \mathrm{dd}, J=11.8$, $2.3 \mathrm{~Hz}, \mathrm{H}-6), 3.71(1 \mathrm{H}, \mathrm{dd}, J=11.8,5.5 \mathrm{~Hz}, \mathrm{H}-6), 3.64(1 \mathrm{H}$, $\mathrm{t}, J=9.3 \mathrm{~Hz}, \mathrm{H}-3), 3.59(1 \mathrm{H}, \mathrm{ddd}, J=9.8,5.3,2.3 \mathrm{~Hz}, \mathrm{H}-5)$, $3.43(1 \mathrm{H}, \mathrm{dd}, J=9.7,3.8 \mathrm{~Hz}, \mathrm{H}-2), 3.33(1 \mathrm{H}, \mathrm{t}, J=9.4 \mathrm{~Hz}$, $\mathrm{H}-4), 2.31$ (2H, t, J=7.2 Hz, H-5'), 1.73-1.66 (4H, m, H-4', $\left.6^{\prime}\right), 1.50-1.20\left(44 \mathrm{H}\right.$, br), $0.94\left(6 \mathrm{H}, \mathrm{t}, \mathrm{CH}_{3} \times 2\right) ;{ }^{13} \mathrm{C} \mathrm{NMR}$ $\left(\mathrm{C}_{5} \mathrm{D}_{5} \mathrm{~N}, 100 \mathrm{MHz}\right) \delta 174.0,171.7,102.3,75.6,75.1,74.2$, $72.5,70.2,65.9,63.2,54.4,36.7,32.5,30.4,30.3,30.3$, $30.2,30.2,30.1,30.0,29.9,29.3,26.6,26.5,23.4,14.7$; FAB-MS $m / z$ 688.1 $\left(\mathrm{M}^{+}+1\right)$; HRMS calcd. for $\mathrm{C}_{38} \mathrm{H}_{74} \mathrm{NO}_{9}\left(\mathrm{M}^{+}+1\right)$ 688.5364, Found: 688.5389; HRMS calcd. for $\mathrm{C}_{38} \mathrm{H}_{73} \mathrm{NNaO}_{9}\left(\mathrm{M}^{+}+\mathrm{Na}\right)$ 710.5183, Found: 710.5168.

Supporting information available. Synthetic procedure, characterization and NMR spectra of new compounds $\mathbf{4}$, 12-17, 19, 21, 24, 26, 29, 36-39, 41, 45-48, and 53.

\section{Acknowledgements}

We thank National Science Council for financial support and a Program Project grant awarded by Academia Sinica.

\section{References and notes}

1. Porcelli, S. A. Adv. Immunol. 1995, 59, 1-98. 
2. (a) Calabi, F.; Jarvis, J. M.; Milstein, C. Eur. J. Immunol. 1989, 19, 285-292. (b) Jackman, R. M.; Moody, D. B.; Procelli, S. A. Crit. Rev. Immunol. 1999, 19, 49-63.

3. Calabi, F.; Bradbury, A. Tissue Antigens 1991, 37, 1-9.

4. Porcelli, S.; Modlin, R. L. Annu. Rev. Immunol. 1999, 17, 297-329.

5. Zeng, Z.; Castano, A. R.; Segelke, B. W.; Stura, E. A.; Peterson, P. A.; Wilson, I. A. Science 1997, 277, 339-345.

6. Natori, T.; Morita, M.; Akimoto, K.; Koezuka, Y.; Agelasphins, Y. Tetrahedron 1994, 50, 2771-2784.

7. Morita, M.; Motoki, K.; Akimoto, K.; Natori, T.; Sakai, T.; Sawa, E.; Yamaji, K.; Koezuka, Y.; Kobayashi, E.; Fukushima, H. J. Med. Chem. 1995, 38, 2176-2187.

8. Kawano, T.; Cui, J.; Koezuka, Y.; Youra, I.; Kaneko, Y.; Motoki, K.; Ueno, H.; Nakagawa, R.; Sato, H.; Kondo, E.; Koseki, H.; Taniguchi, M. Science 1997, 278, 1626-1629.

9. Matsuda, J. L.; Naidenko, O. V.; Gapin, L.; Nakayama, T.; Taniguchi, M.; Wang, C. R.; Koezuka, Y.; Kronenberg, M. J. Exp. Med. 2000, 192, 741-754.

10. Goldsby, R. A.; Kindt, T. J.; Osborne, B. A. Immunology; Freeman: New York, 2000.

11. (a) Hayakawa, Y.; Takeda, K.; Yagita, H.; Smyth, M. J.; Kaer, L. V.; Okumura, K.; Saiki, I. Immunobiology 2002, 100, 1728-1733. (b) Gonzalez-Aseguinolaza, G.; Kaer, L. V.; Bergmann, C. C.; Wilson, J. M.; Schmieg, J.; Kronenberg, M.; Nakayama, T.; Taniguchi, M.; Koezuka, Y.; Tsuji, M. J. Exp. Med. 2002, 195, 617-624.

12. Miyamoto, K.; Miyake, S.; Yamamura, T. Nature 2001, 413, 531-534.

13. (a) Yang, G.; Schmieg, J.; Tsuji, M.; Franck, R. W. Angew. Chem. Int. Ed. 2004, 43, 3818-3822. (b) Goff, R. D.; Gao, Y.; Mattner, J.; Zhou, D.; Yin, N.; Cantu, C.; Teyton, L.; Bendelac, A.; Savage, P. B. J. Am. Chem. Soc. 2004, 126, 13602-13603. (c) Chen, G.; Schmieg, J.; Tsuji, M.; Franck, R. W. Org. Lett. 2004, 6, 4077-4080.

14. (a) Plettenburg, O.; Bodmer-Narkevitch, V.; Wong, C.-H. J. Org. Chem. 2002, 67, 4559-4564. (b) Figueroa-Pérez, S.; Schmidt, R. R. Carbohydr. Res. 2002, 328, 95-102. (c) Takikawa, H.; Muto, S.-e.; Mori, K. Tetrahedron 1998, 54, 3141-3150. (d) Morita, M.; Natori, T.; Akimoto, K.; Osawa, T.; Fukushima, H.; Koezuka, Y. Bioorg. Med. Chem. Lett. 1995, 5, 699-704.

15. (a) Chiu, H.-Y.; Tzou, D.-L.M.; Patkar, L. N.; Lin, C.-C. J. Org. Chem. 2003, 68, 5788-5791 and references cited therein. (b) Lin, C.-C.; Fan, G.-T.; Fang, J.-M. Tetrahedon Lett. 2003, 44, 5281-5283.

16. Barbat, J.; Gelas, J.; Horton, D. Carbohydr. Res. 1991, 219, $115-121$.

17. Liang, C.; Ma, T.; Cooperwood, J. S.; Du, J.; Chu, C. K. Carbohydr. Res. 1997, 303, 33-38.

18. Harcken, C.; Martin, S. F. Org. Lett. 2001, 3, 3591-3593.
19. Tuch, A.; Saniére, M.; Merrer, Y. L.; Depezay, J.-C. Tetrahedron: Asymmetry 1996, 7, 897-906.

20. Zhang, Z.; Ollmann, I. R.; Ye, X.-S.; Wischnat, R.; Baasov, T.; Wong, C.-H. J. Am. Chem. Soc. 1999, 121, 734-753.

21. Nguyen, H. M.; Chen, Y.; Duron, S. G.; Gin, D. Y. J. Am. Chem. Soc. 2001, 123, 8766-8772.

22. Staudinger, H.; Meyer, J. Helv. Chim. Acta 1919, $2,635$.

23. Kondo, H.; Aoki, S.; Ichikawa, Y.; Halcomb, R. L.; Ritzen, H.; Wong, C.-H. J. Org. Chem. 1994, 59, 864-877.

24. Fukunaga, K.; Yoshida, M.; Nakajima, F.; Uematsu, R.; Hara, M.; Inoue, S.; Kondo, H.; Nishimura, S.-I. Bioorg. Med. Chem. Lett. 2003, 13, 813-815.

25. Lin, C.-C.; Hsu, T.-S.; Lu, K.-C.; Huang, I.-T. J. Chin. Chem. Soc. 2000, 47, 921-928.

26. Lin, C.-C.; Shimazaki, M.; Heck, M.-P.; Aoki, S.; Wang, R.; Kimura, T.; Ritzèn, H.; Takayama, S.; Wu, S.-H.; WeitzSchmidt, G.; Wong, C.-H. J. Am. Chem. Soc. 1996, 118, 6826-6840.

27. Grundler, G.; Schmidt, R. R. Carbohydr. Res. 1985, 135, 203-218.

28. (a) Cheng, Y.-P.; Chen, H.-T.; Lin, C.-C. Tetrahedron Lett. 2002, 43, 7721-7723. (b) Demchenko, A. V.; Rousson, E.; Boons, G.-J. Tetrahedron Lett. 1999, 40, 6523-6526.

29. Kunz, H.; Waldmann, H. Helv. Chim. Acta 1985, 68, 618-622.

30. (a) Kobayashi, E.; Motoki, K.; Yamaguchi, Y.; Uchida, T.; Fukushima, H.; Koezuka, Y. Bioorg. Med. Chem. 1996, 4, 615-619. (b) Wang, Y.-Y.; Khoo, K.-H.; Chen, S.-T.; Lin, C.-C.; Wong, C.-H.; Lin, C.-H. Bioorg. Med. Chem. 2002, 10, 1057-1062.

31. Kemeny, D. A Practical Guide to ELISA; Pergamon: Oxford. New York, 1991.

32. Uchimura, A.; Shimizu, T.; Morita, M.; Ueno, H.; Motoki, K.; Fukushima, H.; Natori, T.; Koezuka, Y. Bioorg. Med. Chem. 1997, 5, 2245-2250.

33. Graziani, A.; Passacantilli, P.; Piancatelli, G.; Tani, S. Tetrahedron: Asymmetry 2000, 11, 3921-3938.

34. Motawia, M. S.; Olsen, C. E.; Denyer, K.; Smith, A. M.; Møllera, B. L. Carbohydr. Res. 2001, 330, 309-318.

35. Morita, M.; Sawa, E.; Yamaji, K.; Sakai, T.; Natori, T. Biosci. Biotechnol. Biochem. 1996, 60, 288-292.

36. Costantino, V.; Fattorusso, E.; Imperatore, C.; Mangoni, A. Tetrahedron 2002, 58, 369-376.

37. Zhang, Y.-M.; Brodzky, A.; Sinaÿ, P.; Saint-Marcoux, G.; Perly, B. Tetrahedron: Asymmetry 1995, 6, 1195-1216.

38. Tai, C.-A.; Kulkarni, S. S.; Hung, S.-C. J. Org. Chem. 2003, 68, 8719-8722.

39. Kriek, N. M. A. J.; Filippov, D. V.; Elst, H. V. D.; Meeuwenoord, N. J.; Tesser, G. I.; Boom, J. H. V.; Marela, G. A. V. D. Tetrahedron 2003, 59, 1589-1598.

40. Crich, D.; Cai, W. J. Org. Chem. 1999, 64, 4926-4930.

41. Damager, I.; Olsen, C. E.; Møller, B. L.; Motawia, M. S. Carbohydr. Res. 1999, 1-2, 19-30. 